\title{
Pakistan-United States Diplomatic Relations: Analytical Study
}

\author{
Abdul Rahim \\ PhD Scholar \\ Department of Political Science \\ University of Balochistan \\ Quetta, Pakistan \\ raheem_qta@hotmail.com \\ $\&$ \\ Dr. Adil Zaman Kasi \\ Department of Political Science \\ University of Balochistan \\ Quetta, Pakistan \\ zis.shah@gmail.com
}

\section{ABSTRACT:}

This research paper discusses the reciprocal relationship of Pakistan and United States. Pakistan and United States are engaged in transactional relationship for gaining the credibility of through securing their national interest which bought distractive approaches in bilateral relationship. Historically, Pakistan-United States have been supporting each other against the terrorism as had strong diplomatic alignment in countering terrorism, extremism and fundamentalism. The distrust prevailed and occupied which dismantle the international move to dismantle the terror.

The uncertainty of relationship causes a cataclysmic events which provides distrust as well as dismantle the international coalition for the peace establishment. This paper includes the diplomatic ties between Pakistan and United States specially post 9/11. The diplomatic successful alignment for the international peace brought effective 
orientation thereafter the impact factors of diverse misunderstanding which were mismanaged diplomatically as cases of Raymond Davis, Salala Check post, nuclear proliferation, Osama Bin Laden, Drone Attacks, and Memogate. Their diplopic move is essential to be revamped for the social, economic and political factors which sources the regional peace of South and Central Asia.

Methodology:

The descriptive approach is used to extract the knowledge from secondary sources so as to establish my point of view in supportive act with analytical reasoning.

KEYWORDS: Bilateral, Geo-Economic, Strategy, National interest, Diplomacy

\section{INTRODUCTION}

Pakistan and United States have been ally since the independence of Pakistan as the foreign Policy of Pakistan tilted towards United States for the economic and military support for empowering the new established state. The period had erratic approaches diplomatically, moved but 9/11 brought dramatic change to revise their foreign relation into close alignment so as to confront the Terror and anticipate in War against Terror globally. Ahmed \& Kharal (2015) discussed about the relationship that kept distressed and relaxed for the formation of global agenda.

The phase of Global War on Terror (GWOT) was really problematic for the world but Pakistan suffered more than any one. Pakistan became front line Ally to face the challenges to work-out against the terrorism, moreover Pakistan went on boot to counter the terrorism from Afghanistan. The vision of GWOT was not calculated well and it drifted into Pakistan that hit the economy of Pakistan badly. Pakistan suffered a 
lot and took the decease more than 80,000 (Causalities). The infrastructure was devastated, as well as social and Political fabric was deuterated. United States and West has never been trusting and recognizing the efforts of Pakistan ( Rijinbeek, 2016) though Pakistan tried to secure her national interest on diplomatic front (Rabbi, 2012)

The new world order was announced by the George Bush Senior that converted the world politics towards bipolar system so United States wanted to have supremacy in the word. The cold war was already going on between United States and Russia thereabouts Russia invaded Afghanistan to get maximum resources for this region. United States brought exemplary alignment with Pakistan to defeat Russia in Afghanistan.

The conceptual confidence for the joint operation in Afghanistan was funded by the United States to provide the logistic support, thereafter Islamabad was considered as a trust worthy where national interest was more effectively worked out so United States and Pakistan have been in diplomatic ties which effected bilateral relations (Akhtar, 2012). It is well off that operation of GWAT had reservations in diplomatic relations of Pakistan and United States as trust deficits took place since any joint ally mechanism to confront for regional security (Asghar, 2015). The relationship between United States and India forced Pakistan to go for multilateral relationship as compare to bilateral so Emphatically Pakistan favored geo- Political and economic platform so as to safe her national interest.

Firstly the area of cooperation was well designed that Pakistan and United States had cooperation against terrorism in mode of counter hindrance which had deeps effects on the diplomatic level similarly it is to get anachronistic approach to know how this relation was commenced. The history declares the indicators for tempting the relations in strength or weakness diplomatically.

\section{Historical Perspective}




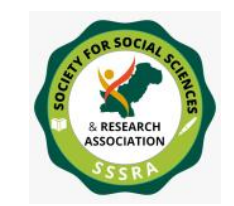

Historically it has been proven that the independence of Pakistan brought two options to join the United States or to be with Russia. The maximum approach for the foreign office was to have economic and military support for the bilateral relationship with United States. (Akhtar, 2012).The balancing the powers in the region was likely known by the Pakistan that reflected to have mutual relationship with the United States (Nadim, 2017) The crises of United States in the region was fully depended on Cold War theory so that Pakistan was the one who could play vital role to get the interest of United States ( Akhtar, 2012).As Pakistan was reliable country to have close relationship for the regional diplomatic efforts through her so Pakistan became trust worthy ally of Untied States in the region( Kux,2001). Pakistan was fully engaged with the United States as economic and military supported country was Pakistan for the south Asia ally (Banerjee \& Commuri, 2014).Pakistan commenced the relationship on the basis of trust so joined SENTO and CENTO in 1954 and 1955. The Mutual Defense Agreement took place in 1954. The concerning agenda for Pakistan was security as it was expected from the United States and in response Southwest Asia and Middle East were concerning to stop the Communism by the United States that needed Pakistan as a regional key member ( Akhtar, 2012) Pakistan received 1.5 Billion Dollars aid thereof 3 Billion Dollars were got for the agricultural and economic assistance from the United States is the biggest example that bilateral relation was fully supported by the Foreign office of both States (Akhtar, 2012). Pakistan has ever tried to support United States by providing the airbase in discipline of comprehensive logistic support so as to provide diplomatic support on practical grounds (Rijnbeek, 2016).

Sino-Indian War, 1962 was the period of distrust when United State supported India. Pakistan was surprised by the State behavior of United States as it was the national interest of United State which shifted towards India (Rijnbeek, 2016). The history declares that Pakistan was the victim as suffered from embargos from United States time by time, in particular 19651971 and 1975 made think of Pakistan to go for multilateral relationships and would try to have less dependency on United States (Javaid, 2014). The diplomatic ties have been grown up for 15 years and 
shaped distrust in diplomatic relations (Bashir \& Mustafa, 2014).

The United States concentration was enhanced diplomatically with India and Pakistan brought a new change with this reference and went to prevent her membership from SENTO and CENTO in 1972 -1979 (Akhtar, 2012). Pakistan went for the enrichment of Uranium for gaining the Nuclear Power so Carter (United States Administration) brought sanctions against Pakistan and stopped aid. Eventually the relationship revised as cold war of Russia and United States went to the War in Afghanistan so Pakistan became frontline foot soldier so as to get help to United States (Kronstadt, 2006). The religious groups of Afghanistan were brought under the umbrella of Jihad and accumulated all for the training under the supervision of Pakistan so as to fight proxy war. The economic aid was sanctioned for this devised move and commenced holy war in Afghanistan (Ahmed, 2002). The Regan government tried to smooth the diplomatic relations with Pakistan, moreover 3.2 Billion Dollars military and economy aid was sanctioned to Pakistan. The second important diplomatic fund was 4.2 Billion Dollars were also released to Pakistan in 1988-93 (Anwar, 2013). The diplomatic relation was again distracted by the Bush Administration to stop the aid due to diverse reasons as military equipment was stopped with the title of Pessler amendments (Kronstadt, 2006). The historical view that Hikmat-Yar got failure to have governing body in Afghanistan (Noor, 2001). The new rising force Taliban fought bravely and took the control of Taliban with the successful rate of fights. That was a conflict between Pushtoons and Northern Alliance as Taliban got the support of Pushtoon to defeat Northern Alliance rapidly. The first recognition of Taliban government was by the Pakistan which kept trust and friendly associated governing system of Pakistan and Afghanistan in the region. The Afghanistan was considered as a strategically depth by the Pakistan. (Rais, 2001; Shah \& Riaz, 2013). The test of Nuclear power of Pakistan had concerns of western countries as it developed critical appraisal by the United States. There could be nuclear proliferation race in the region which would harm the regional peace (Kronstadt, 2006). 1998 the sanctions were imposed on Pakistan by the act 58 "Glenn Amendment" referred the nuclear race in the region Anwar, 2013). The 
military coup of Pakistan was done on October, 1999 causes unrest in the Country and democratic government was dissolved with the abrogation of Pakistan constitution was displeasure for the United States. In response the all the disciplines Aid was restricted and stopped to Pakistan under the Act, section 508 (Akhtar, 2012).

\section{Bilateral Relation Post 9-11}

The event of 9/11 was the source to re think for the articulation of long term strategies through proper Policy execution thereafter mostly countries had stellar effects of their foreign Policies. The super power was hit with the devised strategy and made her suffered, was a challenging enemy who drove to the worst for the West (Ahmed \& Kharral, 2015). It was the first time when the territory of United States was used for the terrorist activities. It was so serious threat to the United States (Javaid, 2011). The responding to the terrorist was very essential so that it got planned by the George Bush to resume the diplomatic relations with Pakistan. Pakistan was asked with one option to be with them or be with terrorist groups. It was a menace to the government of Pakistan which had bad impact on the relationship as diplomatic language was not well delivered by the United States ( Zehra, 2004; Javaid \& Mushtaq, 2014). The serious threat to Pakistan was to fight for securing the interest of United States it was a forceful dictation to be the part of War which made Pakistan to rift her foreign Policy against public opinion of her nation (Shah \& Riaz, 2013). The association was developed by the government of Pakistan and United States therein Pakistan provided air bases with comprehensive logistic support. Pakistan provided intelligence support to find out the housing of Terrorist groups and made CIA to articulate policies. In return Pakistan received aid in reverence of economic and military assistance (Ahmed, 2001). Pakistan got Non-NATO ally status form the United States as well as 3 Billion Dollars were received in account of mutual foreign ally (Kronstadt, 2007). The soldiers in no 2795 were killed along with 21672. 
Civilians 3486 bombs were planted which were blasted in populated areas and 283 Suicide attacks took place. Pakistan reserved approximately 90,000 soldiers (Military and Para Military) forces on the boarder to support the United States in War against Terror. Pakistan suffered a lot as 68 billion were spent in this War till April 2010. The President of Pakistan wrote in his book about the experiences of war and explained the position of Pakistan as He did not have option to join GWOT. Pakistan economy could resist any antagonist approach to the United States similarly United States could put more sanctions on Pakistan which was unbearable economically. The society of Pakistan is already divided on the ethnic basis, was also an undeniable factor. Furthermore, he explained that If Pakistan could not accept then Indian diplomatic efforts were already to engage with United States which was too dangerous for the Kashmir case and nuclear program of Pakistan so Pakistan had to take decision to have associated operations with the United States (Musharraf, 2006).

\section{In the Line of Co-operation}

The co-operation was delivered by the Pakistani regime as George Bush appreciated Musharraf with the comments that he was a brave man and Leader who took decision and played vital role against the extremism which was established by the Al-Qaida and Taliban (Akram, 2002). The bases were handed over freely to have smooth operation, were Shamsi, Dalbandin, Pasni and Jacobabad as well as 100,000 gallon per day oil was pre requisite on Pakistan which was provided without any amount in starting. Pakistan tried to help out in technology with intelligence based coordination. The nuclear sanctions were removed for five years through Ackerman amendment and democratic sanctions were also relaxed by the Presidential (Brownback 2 amendments) moreover the parallel loan was canceled and approved $\$ 600$ million in 2002. Hence 2003 was the year therein 3 billion Dollars were sanctioned and given to Pakistan (Ahmed \& kharal, 2015). The difficult job was to send the logistic support to NATO which became so easy to get them reached through supply line that was provided by Pakistan. (Akhtar, 2012).

\section{Regional Peace and Development}




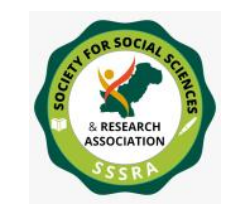

The alignment of Pakistan and United States has been to bring the peace and development in the south Asia region. This region keeps strong build manpower with full of capacity to get resources with logical exactitude thereafter Pakistan, China and other neighboring countries. The example is China which has development figure at the top through the assiduous nation. The worldly businessmen turned to China for their business development as Labor is cheap to produce quality base manufacturing. As far as business hub is concerned it needs peaceful atmosphere which develops developments so Afghanistan, Pakistan and Indian geo economical approach had to be integrated for bringing up the peace in the Region (Akhtar, 2012). The experiences drove to the national interest which affected the global interest and disintegrated Policies of all States brought consequences such as distrust and antagonist feelings for each other. The diplomatic ties increased a lot and both States went into the period of skepticism in their foreign Policy (Banerjee \& Commuri, 2014).

\section{Diplomatic Ties}

Guihong (2003) defined the relationship is always made on the basis of State centric as 9/11 brought closer India with United States so Pakistan is in the form of defensive mode because Pakistan has Kashmir cause and dealings to ha bilateral relations with United States and her motivation to resolve the issue of Kashmir. United States made Civil Nuclear Deal with the India and accepted sovereign nation with

Nuclear Capability in 2005(Evans, 2012). It shows the paradigm shift of United States towards India therein provided 5.5 billion dollar military equipment's to India. It has been very resentment to the Pakistan that scarified her infrastructure with precious lives during the alignment with the United States and in response Pakistan receives a friend who supports her enemy militarily (Farooq and Rashid,2017). The President of United States George Bush entitled that India was a natural partner of United States. This statement was the prediction of her foreign Policy which needed to be understood by the establishment of Pakistan. The nuclear deal with India was a clear menace to Pakistan, commenced blame game that brought diplomatic ties between Pakistan and United States (Ahmed, 2012) Nevertheless the co-operation level was always shaking to stream 
line the Nuclear Issues which was between the United States and Pakistan (Armitage et al, 2010). Pakistan had an option to tilt her foreign policy toward China as geo political scenario goes (Banerjee \& Commuri, 2014).The agreement was done between Pakistan and China for the regional development as 22 treaties were specifically written in September 2005. Similarly, Feb: 2006 President of Pakistan visited to Beijing and stayed there for 5 days with the agenda point of terrorism, trade and strategic development Policies. The visit was likely considered successful efforts of Diplomatic efforts from both sides. Pakistan and China is known as "all-weather friend" is the biggest example of Gwadar port where both Stats are engaged for the geo- economical pimples to formulate the economical connectivity's as one Belt One Road (OBOR) (Kronstadl, 2006). The close relationship of Pakistan and China has been disliked by the United States and it causes diplomatic ties between two nations (Basheer and Mustafa, 2014).

\section{Nuclear Proliferation}

Dr. Abdul Qadeer khan was criticized for the proliferation of nuclear bomb in Jan, 2004. The issue prevailed to identify with the evidences that Pakistan is responsible for the Nuclear Proliferation which has effect on the peace of Society (Fair et al., 2010). Pakistan had black business to have nuclear deal in context of sailing to North Korai, Libya and Iran. The Nuclear deal with other countries are likely to be done against the peace in the region therefore, nuclear proliferation is strongly condemned (Rashid \& LaGuardia, 2004). Pakistan was guilty for the nuclear proliferation (Murphy, 2004; Waheed, 2017). The relation of Pakistan went into gray as United States found evidence that Pakistan was involve in spreading nuclear technology with other countries (Hasan, 2004; Javaid \& Mushtaq, 2014). Similarly China also got engrossed in building two nuclear plants in Pakistan that created a question from China to be intensifying its position that what reasons were to have planted in Pakistan.

\section{Antagonist Feelings}


There have been serious of incidents or Plan of policies that created ambiguities in relation of Pakistan and United States. Firstly Drone attacks in Pakistan brought confusion either it was planned to hit the terrorist or civilians. The disrupted attacks increased the incitement against the government. One side Pakistani government got failed to motivate her nation to explain her position well secondly public opinion developed against the United States. The killing of innocent people brought a hard line stream against the drone attacks. The report was adjusting opinion with $60 \%$ against that United States as an enemy of Pakistan. Secondly two people were badly murdered in bazar by Raymond Davis who was called as private contractor. That has been problematic situation to make him release on the basis of Immunity. The unvarying pressure was developed on Pakistan and here public opinion was generated that Pakistan had dictation of United States. Thirdly, 11 Soldiers were hit by the United States (DAWN, 2012). Thereafter Salala Check post was another element of crises, killed 24 soldiers which was done on November 26, 2011 (Akhtar, 2012). Then next to was $2^{\text {nd }}$ May 2011 when Osama Bin laden was killed in Abbottabad. The relation got disturbed and the image of Pakistan was again questioned by the international community (Kronstadt, 2012). Pakistan was serving in GWOT to have a good image that was distracted as OBL was found in Pakistan and United States had distrust approach against the Policies of Pakistan thereafter relation of Pakistan and United States got detected skepticism and foreign office was in diplomatic ties with Untied States. The question answer session was started to harmonious the relations that was disrupted and went blame game (Rijnbeek, 2016).

\section{F-16 \& Military Financing Program}

Pakistan was relaxed to get jets from united States on discount rate (270 million dollar) in contest of Military Financing Program (MFP), brought an agreement of 699 million Dollar for getting F-16 fighting jets, was refused by the Congress against the charge sheet that Haqqani group was supported by the Pakistani government similarly housing the terrorists in 
Pakistan as well as protection to the nuclear weapons. Pakistani officials expecting to get deal without any condition which could not have been in practice so conflict rose and diverted Foreign Policy to go for an option as Pakistan chose China for geo-economic empowerment which was expecting form the United States. The Foreign Minister advisor stated to go for another option as Russia and China for getting jets for the security purpose as Pakistan defense system requires counter terrorist activities because Pakistan has been in fight for a long, specifically GWOT (Syed, 2016).

Chauhdary (2018). August 2017, The of United States explained the South Asia Policy that determined the intention of United States Foreign Policy .Emphatically, the work of Pakistan was discussed that Pakistan was failure to counter the terrorism where Pakistan received aid to perform better. The slogan words of DO MORE was again asked as Pakistan was forced to have operation against the Haqqani Group despite supporting .Pakistan was considered as distrust ally in GWOT and needed to work more enough to counter the terrorism. The Haqqani group was blamed that they were involved in Killing Afghan and NATO forces in Afghanistan so that Pakistan had to take action against of Haqqani Network. The intelligence agency of United States reported that Pakistan was in supporting role to Haqqani Group and some other terrorist networks which were fully funded by the Pakistan so terror outfits were in through the policy of Pakistan (Kaura \& Era, 2017).

The blame game was re-activated to force Pakistan for the further unrest Pakistan and it got cleared as United States needed an Exit form Afghanistan peacefully. The Pakistani official cleared with the great vision that there were three major sections which is being targeted. Pakistan fought this was bravely so Pakistan became the first enemy of front line for the Al-Qaida and could go for unrest Pakistan through different tactics, secondly another group which really made Pakistan as a failure strategic ally of united States ( Tyreek Taliban Pakistan. (TTP) who were found enemy as Pakistan suffered a lot due to the TTP and their 


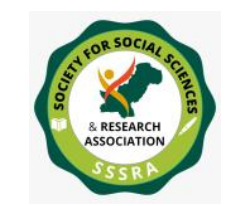

representatives admitted and claimed for the terrorist acts in Pakistan , surly Pakistan went for chasing the enemy to secure het territory. Lastly Taliban from Afghanistan, Haqqani Network and other groups are not involved in terrorist activities in Pakistan so Pakistan did not have to open the new fronts for the sake of United States' interest similarly Pakistan's national interest requires to be having popular foreign Policy which is fully depended on the internal stability of Political system of Pakistan. In response United States went for suspension of Aid to Pakistan that brought diplomatic ties between both States. The demands of United States had imposed on Pakistan to have operation against of Haqqani group so as to be having peace talks with United States, as United States needed a respectable peaceful exit from Afghanistan so it was just possible by the help of Pakistan. Dr, Shahid Afridi who helps United States in killing Osama Bin Laden, was in custody of Pakistan. United States forced Pakistan to handover him to United States caused a bitter diplomatic efforts from the both sides (Bengali \& Sahisep, 2017). Pakistan segregated the terrorist groups who are titled good Taliban and bad Taliban so Pakistan was put into gray list of FATF as UN resolution 1267, Pakistan did not take any strong action against the terrorist groups so Pakistan faced challenges in FATF till now. The two groups named Falah-i-Insaniyat Foundation and Jamaat-ud-Dawa were banned by the Pakistani government to pull herself from gray list of FATF; subsequently The Presidential ordinance was notified in reverence of Anti-Terrorist Act 1997 amended (Younus, 2018). There are seven nuclear trade organizations were critically examined and accused as Pakistan is the member of NSG therein national and international community is displeased because it would be dangerous for the peace of world (Iqbal, 2018). United States tries to pull Pakistan out of NSG so as to empower India and execute the long term Policy to imbalance the South Asia and wants to give power to India for the sustainability of United States' interest in the region. (Global Village Space News Desk, 2018). The diplomatic immunity was given to Colonel Joseph who killed one young guy by road accident (Altaf, 2018). Furthermore, Pakistani police did not arrest him but Pakistani government precautionary listed him in Watch list through the documental evidence to CIA of United States (Chaudhry, 2018). The diplomatic failure which was imposed by the United States as restricted the movement of Pakistani 
diplomats in 25 miles radius so in response Pakistan also committed same principles for the diplomats of United States. It caused disengagement of diplomatic efforts of two States (Janjua \& Harris, 2018).

\section{DISCUSSION \& RESULTS}

Pakistan and United States have been associated since the independence of Pakistan and it got engaged in trust and mistrust diplomatically. United States was not clear and bit mismanaged in her foreign policy to have battle in Afghanistan, similarly Pakistan was not aware to plunge into the war which brought consequences against the political, social and economical structure. The 9-11 brought a sequence of distractive approach in bilateral relationship of Pakistan and United States as Raymond Davis, Salala Check posts, Osama Bin Laden, F-16 Issues, Memo-gate, Drone attacks and Dr. Abdul Qadeer Khan case. The diplomatic relations of both nations were shaking as Donald Trump commenced a new version of pressure to get soft exit from Afghanistan through Pakistan.

The long term policies of ever distracted by the changing the governments as new governing system condemns the old policies and commences the new Policies that distract the long term into short term and it results diplomatic ties between the States. The Policy of ambiguities are kept to initiate new problematic era, needs to have common strategies to entertain some of the policies into ambiguities like Haqani Network or any other that count in supportive act of public opinion.

The integral part is missing to articulate the policy that keeps national interest safe and integrates into global agenda for establishing Policy to gain the credibility of a State. The Indian factor is very important which expects United States to have trust worthy relationship with Pakistan and avoid Indian lobbying to distract the Pakistan. The consistent problem of Afghanistan can be resolved by the assistance of Pakistan as Pakistan worked out to put Taliban and United States on page through the concrete steps. The efforts Pakistan persuades that united States have to be decreasing Indian influence from Afghanistan and would play its vital role to resolve the Kashmir issue as per charter of United Nation. 
The Relationship of Pakistan and United States is ever called Transactional is with the logical exactitude of the history .They are very important for each other but their national interest of more effective than global interest. The transactional relationship has been in hardships as different new diplomatic errors take place. The diplomatic language is also hindering the diplomatic development such as Do More and many other diplomatic pressures that increase the tension between both foreign offices.

Moreover, the bilateral relationship can be expended as Pakistan has had relationship with Russia and China therein foreign office should not ignore the supportive role of United Stated since 1947historically. The relationship of Pakistan is based on national interest and received doubts form the west despite losing 80,000 causalities and damaged her infrastructure. The West ought to know the sacrifices of Pakistan and acknowledge that Pakistan secured the Western interest through unrest Pakistan. The relationship of Pakistan and United States is very important to bring peace and development in the region by commencing strong understands and believing the realistic approaches for the national security of both States.

The establishment of diplomatic office shall be working separately for the better understanding to connect the region to region for the peace and development.

\section{CONCLUSION}

Pakistan and United States relationship brings logical commencement in different periods and their strong alignment changed the political scenario of South and Central Asia. The economic and military cooperation brought footprints for the purposeful national interest to global interest. The peace of entire region was based as diplomatic ties distracted the unstable region and trend of distrust took place after the events as Raymond Davis was arrested and released. The diplomacy turned into skepticism as Salala Check posts were hit and United States had drone 
attacks, undermining the sovereignty of a state. The nuclear proliferation and Osama Bin Laden cases were the revival of ambiguities that enhanced the diplomatic disharmony.

The diplomatic language and bi-lateral relationship with the clear vision for the long term strategic partnership are essential for the regional prosperity. 


\section{References}

Afzal, M. (2018, Jan 12). The Future US-Pakistani Relations. Brookings https://www.brookings.edu/blog/unpacked/2018/01/12/the-future-ofu-s-pakistani-relations/.

Ahmed, J. (2018, Jan 01). Mistrust is the original sin of US-Pakistan relations. The Hill, https://thehill.com/opinion/international/367943mistrust-is-the-original-sin-of-us-pakistan-relations.

Ahmed, N. (2012). Re-defining US-Pakistan Relations. Dialogue (18196462), 7(3).

https://www.qurtuba.edu.pk/thedialogue/The\%20Dialogue/7_3/Dialog ue_July_September2012_211-233.pdf.

Ahmed, S. (2002). The United States and Terrorism in Southwest Asia: September 11 and Beyond. International Security, 26(3), 79-93. https://www.jstor.org/stable/3092090?seq=1.

Akhtar, S. (2012). Dynamics of USA-Pakistan relations in the post 9/11 period: Hurdles and future prospects. International Journal of Humanities and Social Science, 2(11), 205-213.

Akram, Z. (2002). Pakistani-US Relations after 9/11: A Pakistani Perspective. Georgetown Journal of International Affairs, 115-123. https://ciaotest.cc.columbia.edu/olj/gjia/gjia_sumfall02h.pdf.

Altaf, A. (2018, April 07). US defence attaché runs red light, kills motorcyclist. Express Tribune. https://tribune.com.pk/story/1680036/1-man-killed-us-diplomatsvehicle-hits-motorcycle-islamabad/.

Anwar, M. F. (2013). Sanctions as a Tool in US Foreign Policy: A Case Study of Pakistan (1990-2001). Pakistaniaat: A Journal of Pakistan Studies, 5(2), 2245

http://pakistaniaat.org/ doltala/index.php/pak/article/view/224 
Armitage, R. L., Berger, S. R., \& Markey, D. S. (2010). US strategy for Pakistan and Afghanistan: Independent task force report (No. 65). New York: Council on Foreign Relations.

Asghar, A. (2015). Pak-U.S. Relations Re-defined after 9/11. International Research Journal of Social Sciences, 4(1), 74-78. http://www.isca.in/IJSS/Archive/v4/i1/12.ISCA-IRJSS-2014-283.pdf..

Banerjee, S., \& Commuri, G. (2014). A Strange and Bittersweet Relationship: Pakistan-United States Relations in the Musharraf Era. Journal of Asian Security and International Affairs. 1(1), 41-61. https://journals.sagepub.com/doi/abs/10.1177/2347797013518404

Bashir, F., \& Mustafa, G. (2014). Pak-US Security Relation: Challenges \& Prospects for Pakistan. Journal of Social Sciences Anf Humanities (1994-7046), 22(2).

Bengali, S., \& Sahi, A. (2017, Sep 18). After tough Trump speech, Pakistan scrambles to answer U.S. demands in Afghanistan. Los Angeles Times. https://www.latimes.com/world/asia/la-fg-pakistanafghanistan-20170918-story.html.

Chaudhury, D. (2018, Jan 03). Will the new US policy on Pakistan be a test for Donald Trump?. The Economic Times. https://economictimes.indiatimes.com/news/defence/will-the-new-uspolicy-on-pakistan-be-a-test-for-donaldtrump/articleshow/62346120.cms?from $=\mathrm{mdr}$

Chauhdary, S. (2018, April 10). US 'to impose new restrictions' on Pakistani diplomats. The Express Tribune, https://new.tribune.com.pk/story/1682259/1-us-impose-newrestrictions-pakistani-diplomats.

Dawn Web Desk. (2012).Timeline: History of US- Pakistan Relations. https://www.dawn.com/news/731670/timeline-history-of-us-pakistanrelations. 
Evans, A. (2012). The United States and South Asia After Afghanistan. New York: Asia Society.

Express Web Desk. (2018). US reaffirms support to India's NSG bid. The Indian Express. http://indianexp ress.com/agency/express-web-desk/.

Fair, C. C., Crane, K., Chivvis, C. S., Puri, S., \& Spirtas, M. (2010). Pakistan: can the United States Secure an Insecure State? Rand Corporation. https://www.rand.org/pubs/monographs/MG910.html.

Farooq, A. \& Rashid, M. (2017). U.S. Interests in South Asia \& Its Impacts on Regional Stability. Journal of Politics \& International Studies, 3(1), 59-68. http://pu.edu.pk/images/journal/politicsAndInternational/PDF/4_v3_1 _2017.pdf.

Hussain, K. (2018, Feb 24). Pakistan set to be replaced on FATF's Grey List in June. The Dawn, https://www.dawn.com/news/1391342.

Iqbal, A. (2018, March 26). US Sanctions Seven Pakistani Firms for Nuclear Trade. The Dawn, https://www.dawn.com/news/1397628.

Janjua, H. \& Harris, G. (2018, May 11). U.S. Restrict Diplomats' Travel, Adding New Strain on Ties. The New York Time. https://www.nytimes.com/2018/05/11/world/asia/pakistan-us-travelrelations.html.

Javaid, U., \& Mushtaq, I. (2014). Historical Perspective of Pakistan USA Relations; Lessons for Pakistan. South Asian Studies, 29(1), 291-304. https://www.researchgate.net/publication/309462514_Historical_Pers pective_of_Pakistan_USA_Relations_Lessons_for_Pakistan.

Javaid, U. (2011). War on Terror: Pakistan's Apprehensions. African Journal of Political Science and International Relations, 5(3), 125131. https://academicjournals.org/journal/AJPSIR/article-full-textpdf/122C01D40556. 
Kaura, V., \& Era, T. (2017). US-Pakistan relations in the Trump era: Resetting the terms of engagement in Afghanistan. ORF Occasional Paper, (128). https://www.orfonline.org/wpcontent/uploads/2017/12/ORF_Occasion alPaper_128_US_Pakistan.pdf

Kronstadt, K. A. (2006, October). Pakistan: Chronology of Recent Events. Library Of Congress Washington DC Congressional Research Service. https://apps.dtic.mil/dtic/tr/fulltext/u2/a464774.pdf

Kronstadt, K. A. (2007, August). Pakistan-US Relations.Washington: District of Coloumbia: Congressional Rearch Service Report for Congress.

Kronstadt, K. A. (2012). Pakistan-US relations. Washington, DC: Congressional Research Service. https://www.files.ethz.ch/isn/130531/R41832.pdf

Murphy, J. (2004, August 24). Pakistan probes nuke tech leak. CBS News. http://www.cbsnews.com/news/pakistan-probes-nuke-tech- leak-1901-2004/

Musharraf, P. (2006). In the line of fire: A memoir. London: Simon and Schuster..

Nadim, H. (2017). Neither Friend nor Foe: Pakistan, the United States and the war in Afghanistan. Lowy Institute. https://www.jstor.org/stable/resrep10178?seq=1\#metadata_info_tab_c ontents.

News Desk. (2018, March 26). US sanctions Pakistani companies to set stage for NSG Meeting in April? Global Village Space. https://www.globalvillagespace.com/us-sanctions-pakistanicompanies-to-set-stage-for-nsg-meeting-in-april/.

Noor, A. (2001, September 30). The Neighbor Within. The News, 4. 
Rabbi, F. (2012). War against Terrorism and its Repercussions for Pakistan. Pakistan Journal of History and Culture, 33(2), 71-90.

Rais, R. B. (2007). Identity politics and minorities in Pakistan. South Asia: Journal of South Asian Studies, 30(1), 111-125. https://www.tandfonline.com/doi/abs/10.1080/00856400701264050?j ournalCode $=\operatorname{csas} 20$

Rijnbeek, K. J. H. F. (2016). The United States and Pakistan: A Relationship Tainted by US Polarized Interests. American Studies, $1-$ 37

Sattar, A. (2010). Pakistan's Foreign Policy, 1947-2009: A Concise History. Oxford: Oxford University Press.

Shah, J., \& Riaz, N. (2013). September 11, 2001 and Change in Pakistan's Foreign Policy. American International Journal of Contemporary Research, 3(1), 97-1.

Syed, B. (2016, May 28). F-16 deal expires amid Pakistan-US row over finances. The Dawn. https://www.dawn.com/news/1261205\#: :text=ISLAMABAD\%3A\% 20Pakistan $\% 20$ seems $\% 20$ to $\% 20$ have, following $\% 20 \mathrm{a} \% 20$ row $\% 20$ ove r\%20financing.\&text $=\%$ E2\%80\%9CPakistan $\% 20$ decided $\% 20$ not $\% 20$ to $\% 20$ fully, $\% 2 \mathrm{C} \% \mathrm{E} 2 \% 80 \% 9 \mathrm{D} \% 20$ the $\% 20$ source $\% 20$ told $\% 20 \mathrm{Dawn}$.

Waheed, A.W. (2017). Pakistan's Dependence and US Patronage: The Politics of 'Limited Influence. Journal of Asian Security and International Affairs, 4(1), 69-94.

Younus, U. (2018, March 01). How will being on the FAFT Grey list actually impact Pakistan? The Diplomat.

https://thediplomat.com/2018/03/how-will-being-on-the-fatf-grey-listactually-impact-pakistan/.

Zehra, N. (2004, April 8). Comment: The Paradox of Pakistan - US Relations. The Gulf News, 
https://gulfnews.com/world/asia/pakistan/comment-the-paradox-ofpakistans-relations-with-the-united-states-1.318966. 